\title{
The Collaborative Effect of Sustainable Project Management (SPM) and Benefits Management (BM) on Project Success: with the Influencing Force of Project Governance
}

\author{
Imran Khan, Muhammad Awais, Waqar Alam, and Aftab Alam
}

\begin{abstract}
This research study investigates the relationship between sustainable project management (SPM) and benefits management (BM) on Project success (PS) with the influencing force of project governance (PG). The data was collected from the 207 employees and executive's authorities of construction companies working in Pakistan. The convenience sampling was used for data collection. The results of the study show that SPM and BM has significant effect on PS. While the project governance (PG) is significantly influence the relationship. Moreover, another imperative discovery was made that the indirect combine effect of SPM and BM on PS is also significantly increased the project success rate.
\end{abstract}

Index Terms - Sustainable Project Management, Benefits Management, Project Success, Collaborative effect, Project Governance, Construction Companies in Pakistan.

\section{INTRODUCTION}

Project success is one of the most explored areas in project management, but the meaning of the term "success" varies substantially [1]. However, there is extensive literature on the traditional project performance characteristics including time, cost, quality, and innovations [2]; the benefits of sustainability in sustainable project management have gained less attention. Additionally, in past, the construction and infrastructure management research studies have typically concentrated on investment projects, [3]. Therefore, the factor of sustainability in project management (SPM) can help the project managers for achieving more reliable project success rates. But, still the degree of this objective is reached unidentified as projects still fail to reach their goals [4] and the significance of SPM on PS is still missing.

To ascertain the project success, researchers and practitioners have focused on sustainable project-based management [5] which enhances project success rates as evident from [41] which resulted that there is a significant decrease in wasting cost in investments. Still, various projects have failed which is a major challenge of sustainably in projects therefore, many other success factors have been examined [11].

Published on November 28, 2020

Imran Khan, Abasyn University Peshawar, Pakistan.

(corresponding e-mail: ik202049@gmail.com)
The concept of sustainability in project management is considered as the most significant factor that affects project success which is a tool to select the right projects at the right time and carry out the projects on time, within budget to meet client satisfaction including 'Three-P (People, Planet, Profit)' concept [6]. Therefore, sustainable project management (SPM) is the requirement of project success [15] which is not only inevitable but essential for the development of successful projects [16]. However, It has been seen in the past literature, that project success has not been improved significantly by applying project management processes, tools, and systems alone as evident from the study that $45 \%$ of the difference is due to PM performance while, the 55\% discrepancies leftover unsolved therefore other influencing factors of project success which needs to be explored [18].

Benefits Management (BM) has associated with project success and focusing benefits can advance the project's success [19]. Moreover, BM has categorized in a set process and procedures to certify the projects, activities, and project portfolios that achieve the aim of business strategy topically, to make the organizational value productively and sustainably [20]. According to [21] the processes of BM are organizing and managing the prospective benefits created from the usage of information technology is correctly recognized. Recently, project management researchers have encouraged organizations/ firms to focus on benefits management [22]. Moreover, [20] reported that benefits management is the ideal incentive for financing firms. However, the recognition of benefits is the necessary component of PS [23]. Currently, various researchers proposed the factor of BM creates value and much important for each project to increase the capability of PG [24]. Moreover, benefits management along with other project management practices needs to be applied so that complete management of project performance is ensured, and organizational strategic goals are achieved therefore a constant $\mathrm{BM}$ process is required [25].

According [26] the PG as a "value system, responsibilities, procedures and policies that allows projects to accomplish organizational targets and encourages the implementation of

Muhammad Awais, Abasyn University Peshawar, Pakistan.

Waqar Alam, Abasyn University Peshawar, Pakistan.

Aftab Alam, Abasyn University Peshawar, Pakistan. 
best interests of all stakeholders, (internal, external) and the corporation itself'. Moreover, the PG emphases on projects and provides guidance on how the PM processes are lead throughout the project life cycle [27]. PG is one of the important factors of successful projects. It significantly influences the project quality and great effects on success parameters. According to [28] project success is extremely dependent on the capability of PG. Moreover, the effective presence of PG is essential for PS. Additionally, PG plays a vital role in decision-making processes. It provides guidance to control project plans, activities, and project stakeholders [29]. According to [30] the successful PG system aims to streamline the outcome, objectives, goals, and strategies of the firms. Hence, PG ensures the inputs and outputs of the project lead to the ideal results [31].

This research study provides a better understanding regarding the combined effect of SPM, BM on PS, and how PG makes this relationship more effective. Therefore, the study proposed the following research questions: what is the collaborative effect of SPM, BM on PS by analyzing the moderating role of project governance PG? What unit of analysis is proposed to explain the relationship between the SPM, BM, PS, and PG? For the current study, the conceptual framework is based on agency theory with supportive arguments of stewardship theory and classical management theory to answer the research questions.

This research intends to fill the identified knowledge gaps and doing so makes several contributions. First, the major and novelty contribution of this study is to measures the combine effect of SPM and BM on PS. Second, it also measures the direct relation of SPM and BM on project success. Third, this study also elaborates whether PG as a moderator between SPM, BM, and PS. This empirical evidence can help to provide a window to understanding the moderating mechanism through which PG influences SPM, BM, and PS. To better understanding the moderating mechanisms between SPM, BM, and PS, it would enable us to clear theoretical understanding of the relationship. Fourth, limited research exists in the literature about the relationship between SPM, BM, and PS. This research study would improve the project management body of knowledge and will improve the conceptual clarity regarding SPM, BM, and PS with influencing force of PG in the organizations. Additionally, this research study helps organizations to understand how collectively align SPM and $\mathrm{BM}$ practices to enhance their effectiveness, which should result in higher project success rates.

\section{THEORETICAL CONTRIBUTION}

Theories streamline the research direction and help us to reach our objectives. The existing research study links the variables through the contribution of agency theory, Stewardship theory and classical management theory.

[33] Proposed the agency theory and [33] was further categorized through the conflict of interest between executives and managers in organizations or firms. The conceptual framework of this study closely linked and supported the argument that an effective PG mechanism ensures the project success rate. Nonetheless, the week governance structure effect sustainability parameters of SPM on PS. additionally, the contribution of an effective PG system is also supported through stewardship theory. Hence, both theories explain the combining effect of SPM and BM that ultimately enhance the PS. Conditional bits of PS link a strong association between PG and BM. However, the proposed conceptual framework is also supported by the classical management theory, where authority encounters with dissimilar employees behavior, and overall addressing the governance's attitudes and their competence towards PS.

Therefore, this conceptual framework is the best fit in the model and can create a logical explanation between the constructs.

\section{LITERATURE REVIEW AND HYPOTHESES DEVELOPMENT}

A comprehensive concept of sustainability depends on the combination of three dimensions social economic and environmental, which established the renowned TripleBottom-Line (TBL), or "Three-P (People, Planet, Profit)" concept that acknowledges very widely [34]. These three dimensions of sustainability have also been phrased as "ecology, economy and equity" (UN Report on Prototype Global Sustainable Development).

According to the sustainability literature review, there are various analytical tools to measures the basic performance indicators have been testified to managing and ensuring sustainability [37]. Characteristically, these indicators are used throughout the project phases of initiating and planning, additionally, these indicators are also used to measures the monitoring and implementation phase (Aarseth et al., in press). Moreover, these indicators vary specific case wise which covers several dimensions of sustainability [37], and to achieve the mutable goals of diverse project stakeholders [38]. Moreover, according to [39] the empirical outcome of using sustainability indicators varies. According to [40] generally, the suggested indicators fail to achieve the mentioned goals regarding three dimensions of sustainability (Social, economic and environment).

\section{A. Sustainable Project Management (SPM)}

Sustainability is about the sense of balancing or synchronizing the triple bottom line (TBL) of sustainability i.e. economic, social, and environmental [40]. The triple bottom line (TBL) concept captures the spirit of sustainability by determining the impact of organizational activities across the world. Whereas a project is temporary, unique, and complex with well-defined start and end time, scope, resources, properly designed to achieve specific goals by following the predetermined set of operations and procedures [41]. The complex nature projects required a lot of useful resources and a considerable amount of finances, which is essential for the completion of the entire project modalities by close interaction with the external environment [42]. 
Research on sustainable project management has gained much interest over the recent past. It plays an important role in the accomplishment of a project's basic goals, objectives, and undertakings. "Sustainable Project Management is the planning, monitoring and controlling of project delivery and support processes, with consideration of the environmental, economic and social aspects of the life-cycle of the project's resources, processes, deliverables, and effects, aimed at realizing benefits for stakeholders, and performed in a transparent, fair and ethical way that includes proactive stakeholder participation". The definition of SPM indicates a more holistic approach related to projects by engaging multiple stakeholders in different project management activities [43] and get the deliverables in terms of social environmental and financial. Sustainability involved three dimensions environmental, economic, and social also called triple bottom line or Triple-P (People, Planet, and Profit). To recognize the contribution of sustainable development, the three parameters of SPM are considered significant. As all these dimensions are interrelated with each other [34]. Nonetheless, the research studies on sustainable development focus on the economic dimension most commonly and its association with the environmental parameter. [40]. finally, the projects play an important role in understanding other sustainable business Practices [40]. But, for sustainably, the environmental, economic, and social pieces are rarely considered and given minimum weightage in temporary organizations that are formed to implement projects [54]. In recent literature, there are five dimensions of sustainable project management: such as corporate policies and practices, resource management, life cycle orientation, stakeholder engagement, and organizational learning [53].

\section{B. Benefits Management (BM)}

The dynamic force of benefits management (BM) holds all the organized management procedures and strategies [41]. The concept of benefits management (BM) was practiced in past literature to increase the success to information technology related projects [27]. According to [25], the benefits management $(\mathrm{BM})$ has diverted its importance to other industries too. The adjustments change in business could cause of few side effects, for instance, they might require various extra skills or increase cost, which reflects the negative outcomes. Moreover, these negative outcomes and the objectionable effects might make the stakeholders acknowledge more benefits. According to [27] the medium size of benefits critically becomes a source to obtain the less important benefits. This kind of business is considered profitable for those who invest on a huge scale to the organization and as well as its workers, clienteles, and indirect stakeholders. Hence, the investments for any kind of change is not acceptable if it is not beneficial for direct or indirect stakeholders. Therefore, the initiatives for change are permanently controlled by benefits management (BM).

\section{Project Success (PS)}

The success of any project can be measured by either project success criteria or success factor, as both often appear in the literature [59]. First of all, there is a differentiation between these two terms. Success factors are those which constitute, influence, and determine the success of a project. It enables a project manager to increase the likelihood of successful completion of the undertaken project, without having demarcated levers to apply during the project implementation phase available to him. However, the success criteria are to determine the project in terms of success or failure [50]. In past literature, various researchers and practitioners suggested that quality; cost, and time can be used as criteria in measuring the degree of project success [54].

A project is said to be successful if the triple constraints concepts as proposed in the iron triangle are eventually acknowledged throughout the project works [50].

\section{Project Governance $(P G)$}

The concept of project governance is defined by PMI as an oversight function that is aligned with the organization's governance model and that encompasses the project life cycle [41]. The factor of project governance acquired prominence since 2005 [30]. Based on limited literature, it determined that good governance could lead to drastic changes with improvement in project outcomes. The concept of governance is a highly considerable part of project management [41]. There are several pieces of effective governance. For instance, a massively collective view is that it comprises the comparison of leadership styles, structure, and decision-making processes to make the projects produce value while minimizing the risk factors [52]. Similarly, [24] explains that project governance may be classified as a system based on a process that strategically directs projects, manages it interactively, and controls it holistically by reflecting the factors of entrepreneurial and ethical manners. To focus on temporary projects [33], they need a specific structure of governance, and however, the relatively established types of organizations must still exist side by side with them. According to [53] the factor of accountability in the concept of project governance holds prominent value. The project success rate relies on the wise allocation of resources between all the projects and all its relevant supporting procedures with the highest level of a corporation [54]. The term governance is considered to be effective at a higher level than the management as it established such processes, procedures, and structures that support management [55].

\section{E. Sustainable Project Management (SPM) and Project Success (PS)}

Sustainability in project management is considered as the most significant factor that affects project success which is a tool to select the right projects at the right time and carry out the projects on time, within budget to meet client satisfaction including "Three-P (People, Planet, Profit)" concept [6]. Sustainability can contribute significantly to project success. [57] developed a research model that investigates the 
relationship of SPM with PS; they concluded that project sustainability management has a positive and significant impact on project success dimensions. [42], reported in their study and answer the question "does sustainability in project management contribute to project success? As a result, a set of key variables is presented relating to sustainability in project management and project success". Furthermore, extensive literature found that the positive impact has occurred between sustainably in project management and project success. According to [42], the development of sustainability in project management leads to project success. Similarly, [60] found significant relationship between sustainability and project success. Moreover, with the help of the model, a comprehensive understanding of how the different parameters of sustainability may affect the project success rate. In light of this evidence, the first hypotheses developed.

$H_{l}$ : There is a significant Impact of sustainable project management on project success

\section{F. Benefit Management (BM) and Project Success (PS)}

Benefits Management has an association with project success and focusing benefits can advance the project's success [19]. Moreover, benefits management along with other project management practices needs to be applied so that complete management of project performance is ensured and organizational strategic goals are achieved therefore a constant BM process is required [25] However, the element of BM into organizations and its following usage in those organizations have very limited empirical evidence that PM and BM combine can enhance the project success considerably [27]. Moreover, [27] reported the relationship between organizational cultures such as governance and knowledge management and the use of benefit management methods and practices needs to be investigated. On the bases of this empirical evidence, the second hypothesis has been developed.

$\mathrm{H}_{2}$ : There is a significant impact of benefits management on project governance

G. Collaborative Effect of Sustainable Project Management (SPM), Benefits Management (BM), and Project Success (PS)

The relationship of sustainable project management (SPM) and Benefits Management (BM) and their focusing benefits can advance the project success [19]. Moreover, Benefits Management along with other sustainable project management practices needs to be applied so that complete management of project performance is ensured, and organizational strategic goals are achieved therefore a constant BM process is required [25]. However, the BM practices in organizations and its following usage in those organizations have very little empirical evidence, that is why by connecting SPM and BM can enhance the project success considerably [27]. Therefore, the following hypotheses have been developed.

$H_{3:}$ There is a significant impact of collaborative effect sustainable project management, benefits management on project success
H. Project Governance as a Moderator between Sustainable Project Management, Benefits Management, and Project Success

In past literature, limited research work exists between the project governance PG, sustainable project management SPM, benefits management BM, and project success PS. According to [1] the selection of a project management methodology is also influenced by project governance. Similarly [12] found that project governance is an enabler of teamwork and an indication that it has a little, but the important association with project success. However, to increase the ability of organizations to define and manage their success criteria, the addition of benefits management plan into the project governance processes need to be done [19]. Additionally, researchers found that project governance is one of the most prominent features that help the execution of steady benefit management in projects. Moreover, the project governance increases project success directly as well as through an improved benefit management procedure. However, it depends on the project owner and his adoption of benefits realization mindset which results in improving project success [15]. Hence, the fourth and fifth hypotheses developed.

$H_{4:}$ Project Governance as a moderator between sustainable project management, and project success

$H_{5}$ : $\quad$ Project Governance as a moderator between benefits management and Project success

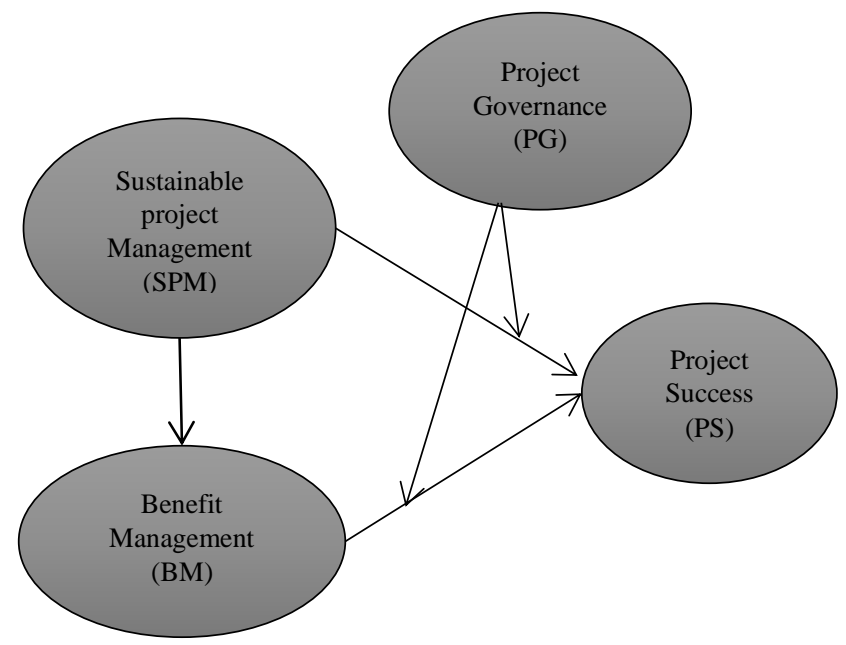

Fig. 1. Conceptual framework.

\section{Methodology}

\section{A. Data Collection and Sample Size}

This research is cross-sectional and quantitative. For data collection, a convenience sampling technique was applied and 320 questionnaires were distributed amongst project managers, project coordinators, engineers, site engineers, supervisors, and executives of the different construction companies of Pakistan. A total of 207 questionnaires were selected for analysis. The sample size seems appropriate as prior research had similar or less sample size [58]. 


\section{B. Measures}

The variables scales were adopted from the past literature by using the 5-Likert scale including strongly agree to strongly disagree. The scale of SPM consists of 14 items and the same adopted from the study of [56]. However, 14 items for PS were adopted from the study of [17]. For the measurement of BM, 12 items were adapted from the scale of [31]. Similarly, 9 items for PG were adopted from the study of [31]. For data analysis smart PLS-3.2.8 software was used for testing the variables.

\section{RESUlTS}

\section{A. Structural Model and Hypotheses Testing}

To access the measurement model the study calculates outer loadings, Cronbach's alpha, composite reliability, convergent validity, and discriminant validity (Table 1,2). The acceptable range of outer loadings is $>0.50$. Thus, the outer-loading of all items lies in an acceptable range. The acceptable range of composite reliability is 0.7 . The result shows that all the variables possessed higher composite reliability. However, the normal range of Cronbach's coefficient alpha is 0.7. The results indicated that reliability has been well recognized by using Cronbach's alpha. The acceptable range of average variance extracted (AVE) is 0.5 . The existing study shows that all the constructs hold convergent validity. For discriminant validity the acceptable range of HTMT ratio is $<0.9$ and the relevant confidence interval up to 1 . The result show that HTMT values and confidence of interval values of each construct are less than 0.9 and I respectively.

TABLE 1: RELIABILITY AND CONVERGENT VALIDITY

\begin{tabular}{|c|c|c|c|c|c|c|}
\hline \multirow[t]{2}{*}{ Variables } & \multirow[t]{2}{*}{ Items } & \multirow{2}{*}{$\begin{array}{c}\text { Outer } \\
\text { loading }\end{array}$} & \multicolumn{2}{|c|}{$\begin{array}{l}\text { Composite } \\
\text { reliability }\end{array}$} & \multirow[t]{2}{*}{$\begin{array}{c}\begin{array}{c}\text { Cronbach's } \\
\text { Alpha }\end{array} \\
>06\end{array}$} & \multirow{2}{*}{$\begin{array}{r}\text { AVE } \\
>0.5 \\
\end{array}$} \\
\hline & & & & & & \\
\hline \multirow{4}{*}{$(\mathrm{SPM})$} & SPM11 & 0.835 & \multirow{4}{*}{\multicolumn{2}{|c|}{0.898}} & \multirow{4}{*}{0.849} & \multirow{4}{*}{0.687} \\
\hline & SPM13S & 0.834 & & & & \\
\hline & PM14 & 0.834 & & & & \\
\hline & SPM9 & 0.813 & & & & \\
\hline \multirow{6}{*}{ (BM) } & BM10 & 0.841 & \multirow{6}{*}{\multicolumn{2}{|c|}{0.950}} & & \multirow{7}{*}{0.761} \\
\hline & BM11 & 0.883 & & & & \\
\hline & BM5 & 0.878 & & & 0937 & \\
\hline & BM7 & 0.912 & & & 0.951 & \\
\hline & BM8 & 0.858 & & & & \\
\hline & BM9 & 0.862 & & & & \\
\hline \multirow{5}{*}{ (PS) } & PS 10 & 0.864 & \multirow{5}{*}{\multicolumn{2}{|c|}{0.923}} & & \\
\hline & PS13 & 0.846 & & & & \multirow{4}{*}{0.705} \\
\hline & PS14 & 0.832 & & & 0.896 & \\
\hline & PS6 & 0.829 & & & & \\
\hline & PS9 & 0.828 & & & & \\
\hline \multirow{11}{*}{ (PG) } & PG2 & 0.844 & \multirow{5}{*}{\multicolumn{2}{|c|}{0.932}} & & \multirow{5}{*}{0.732} \\
\hline & PG4 & 0.833 & & & & \\
\hline & PG5 & 0.841 & & & 0.908 & \\
\hline & PG7 & 0.866 & & & & \\
\hline & PG8 & 0.891 & & & & \\
\hline & \multicolumn{5}{|c|}{ TABLE 2: DISCERNMENT VALIDITY } & \\
\hline & & $\mathrm{M}$ & PS & PG & SPM & \\
\hline & BM & 373 & & & & \\
\hline & PG & 761 & 0.855 & & & \\
\hline & PS & 755 & 0.792 & 0.840 & & \\
\hline & SPM & 583 & 0.651 & 0.745 & 0.829 & \\
\hline
\end{tabular}

Hypotheses testing by calculating the direct impact (Table 3). HI evaluates whether SPM has a substantial impact on PS. The results showed that SPM has a significant effect on $(\beta=$ 0.712 , t- 17.906, p < 0.000), thus H I supported. H2 states that $\mathrm{BM}$ has a substantial effect on PS. The result indicated that there is a significant effect of BM on PS BM $->$ PS $(\beta=0.272$, $\mathrm{p}<0.000$ ), therefore, $\mathrm{H} 2$ accepted. $\mathrm{H} 3$ reported that whether SPM has a significant impact on BM. The result showed that SPM significantly affects SPM $->B M(\beta=0.683, p<0.000)$. Thus, H3 is supported.

TABLE 3: HYPOTHESES TESTING

\begin{tabular}{cccccc}
\hline & Beta & $\begin{array}{c}\text { Standard } \\
\text { Deviation } \\
\text { (STDEV) }\end{array}$ & $\begin{array}{c}\text { T Statistics } \\
(\mid \mathrm{O} / \text { STDEV })\end{array}$ & $\begin{array}{c}\text { P } \\
\text { Values }\end{array}$ & Decision \\
\hline $\begin{array}{c}\text { H2: BM -> } \\
\text { PS }\end{array}$ & 0.272 & 0.069 & 3.959 & 0.000 & Supported \\
$\begin{array}{c}\text { H3: SPM - } \\
\text { > BM }\end{array}$ & 0.683 & 0.038 & 17.841 & 0.000 & Supported \\
$\begin{array}{c}\text { H1: SPM - } \\
>\text { PS }\end{array}$ & 0.249 & 0.057 & 4.352 & 0.000 & Supported \\
\hline
\end{tabular}

\section{B. Moderation Effect}

To access the moderation results, we performed a bootstrapping procedure through Smart PLS-3. H4 reported that whether PG moderates between SPM and PS. The results show that PG significantly moderates between SPM and BM. SPM * PG -> PS $(\beta=0.179, \mathrm{p}<0.000)$. Hence, H4 supported. H5 stated that whether PG moderates between BM and PS. The results show that $\mathrm{PG}$ significantly moderates between $\mathrm{BM}$ and PS BM * PG $->$ PS $(\beta=0.114, p<0.25)$. Thus, H5 is accepted.
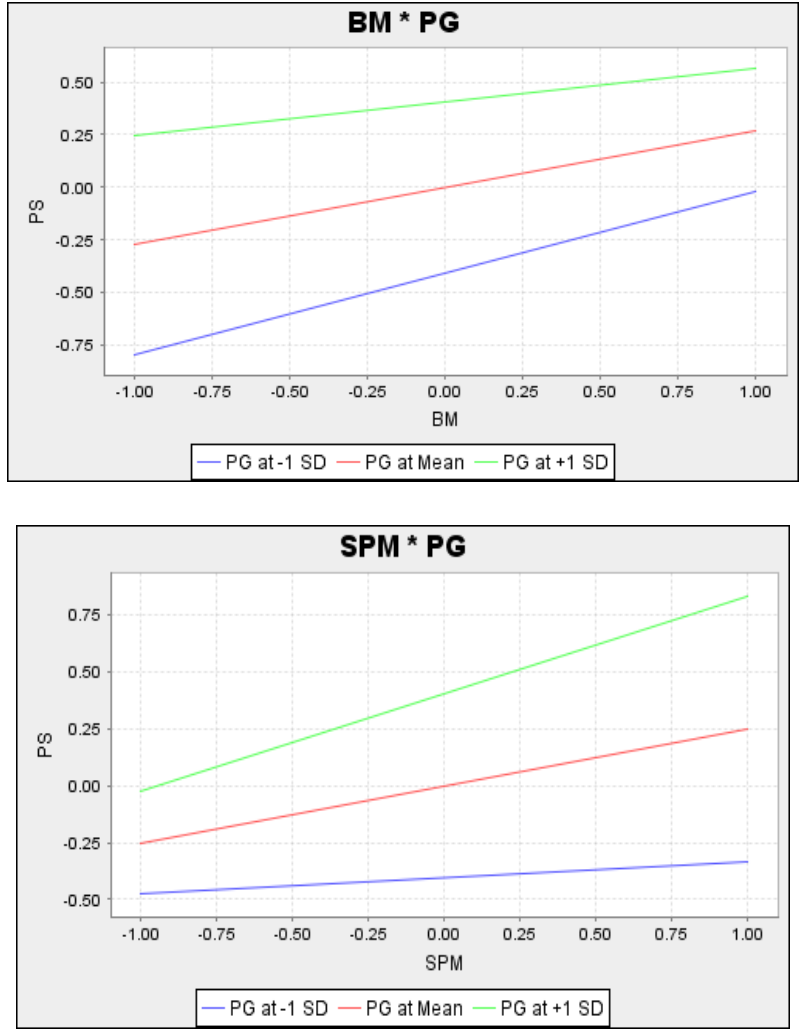

Fig. 2. Graphical representation of Moderation effect 
TABLE 4: MODERATING EFFECT

\begin{tabular}{cccccc}
\multicolumn{6}{c}{ TABLE 4: ModERATING EFFECT } \\
\hline & Beta & $\begin{array}{c}\text { Standard } \\
\text { Deviation } \\
\text { (STDEV) }\end{array}$ & $\begin{array}{c}\text { T Statistics } \\
(\mid \mathrm{O} / \text { STDEV })\end{array}$ & $\begin{array}{c}\text { P- } \\
\text { Values }\end{array}$ & Decision \\
\hline $\begin{array}{c}\text { SPM * } \\
\text { PG -> } \\
\text { PS }\end{array}$ & 0.179 & 0.045 & 3.963 & .000 & Supported \\
$\begin{array}{c}\text { BM * } \\
\text { PG -> } \\
\text { PS }\end{array}$ & 0.114 & 0.051 & 2.248 & 025 & Supported \\
\hline
\end{tabular}

\section{Coefficient of Determination $\left(R^{2}\right)$ and Predictive relevance} $\left(Q^{2}\right)$

The coefficient of determination $\left(\mathrm{R}^{2}\right)$ is calculated to gauge the power of the model. (Fig. 3) indicates that the results of the structural equation model analysis. Each construct SPM (54\%), BM (46\%), and PS (76\%) shows the acceptable range $(>50)$ of $\mathrm{R}^{2}$. Hence, the proposed model has moderate level predictive power to explain the project success parameters.

To find the predictive relevance of structural model $\left(Q^{2}\right)$ is assessed. It can help in understanding whether the constructs are predicted correctly by its indicators in the reflective model. The results indicated that $75 \%\left(\mathrm{R}^{2} 0.756\right)$ change reported in project success $46 \%\left(\mathrm{R}^{2} 0.467\right)$ variance accounted in BM due to SPM which reflects the model's sufficient predictive accuracy.

Applying the blindfolding technique to measure the $\left(\mathrm{Q}^{2}\right)$ value of SPM, BM and PS are $\mathrm{R}^{2} 0.756$ and 0.467 and which are greater than zero, then to describe robust predictive relevance of the SEM framework.

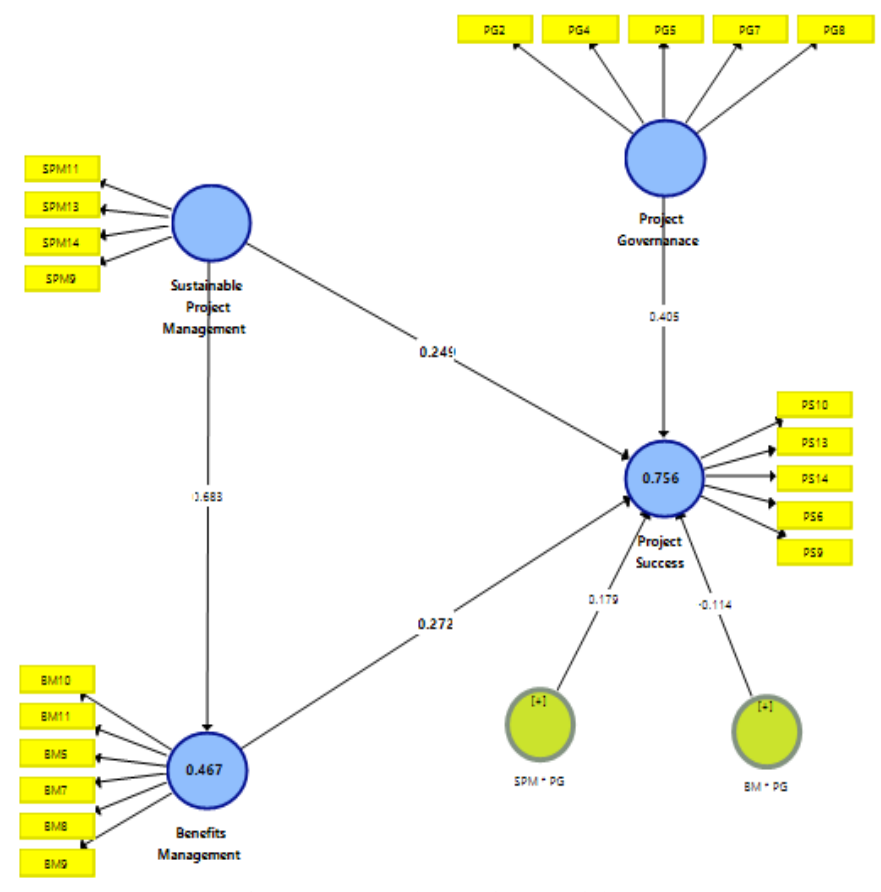

Fig. 3. Structural Equation Model.

\section{DISCUSSION}

Sustainability in project management is considered as the most significant factor that affects project success which is a tool to select the right projects at the right time and carry out the projects on time, within budget to meet client satisfaction including 'Three-P (People, Planet, Profit) concept [6]. On the bases of this empirical evidence, the first hypotheses of the study $\mathrm{H} 1$ reported that SPM has a significant effect on PS. The supporting argument $\mathrm{H} 1$ [57] investigates the relationship of SPM with PS; they concluded that project sustainability management has a significant effect on project success dimensions. The second hypothesis $\mathrm{H} 2$ evaluates that $\mathrm{BM}$ has a significant effect on PS. The BM has an association with project success and focusing benefits can advance the project's success [19]. Moreover, benefits management along with other project management practices needs to be applied so that complete management of project performance is ensured, and organizational strategic goals are achieved therefore a constant $\mathrm{BM}$ process is required [41]. The third hypothesis H3 concentrates the combined effect of SPM, BM on PS. The indirect effect of SPM -> BM -> PS is 0.186. It indicates that SPM and BM collectively increased the project success rate by $0.186 \%$. The relationship of sustainable project management (SPM) and benefits management (BM) and their focusing benefits can advance the project success [19]. Moreover, benefits management along with other sustainable project management practices needs to be applied so that complete management of project performance is ensured, and organizational strategic goals are achieved.

$\mathrm{H} 4$ evaluates that PG is the influencing factor between SPM and PS. The results of this hypothesis show that PG strongly influences the relationship between SPM and PS. According to [1] the selection of a project management methodology is also influenced by project governance.

The project governance is an enabler of teamwork and an indication that it has a little, but the important association with project success [11]. Moreover, according to [31] the project governance increases project success directly as well as through an improved benefit management procedure. However, it depends on the project owner and his adoption of benefits realization mindset which results in improving project success.

The outcome of final hypotheses H5 reported that PG moderates between $\mathrm{BM}$ and PS. The results describe that PG influences the relationship between BM and PS. According to [33], temporary projects need a specific structure of governance, and however, the relatively established types of organizations must still exist side by side with them. According to [53] the factor of accountability in the concept of project governance holds prominent value. The project success rate relies on the wise allocation of resources between all the projects and all its relevant supporting procedures with the highest level of the corporation [49]. The term governance is considered to be effective at a higher level than the management as it established such processes, procedures, and structures which support management [55]. 


\section{LIMITATION AND FUTURE DIRECTIONS}

This study has certain limitations that should need to be highlighted. This study has conducted comparatively with a small sample size. For future studies, larger sample size may facilitate the researchers to generalize their study results. This is a cross-sectional study their results represent the short questions scenario of collaborative effect of sustainable project management (SPM) and benefits management (BM) on Project success (PS) with moderation effect of project governance (PG). In the future, the researchers could apply the longitudinal method for more detailed investigation. The current study focus on SPM and BM for PS. Future research should be focused on other relevant variables that can improve the project success rate. Finally, the current study only focused on one moderator that influence the relationship. For future studies incorporate more relevant moderators and mediators that can influence the relation more effectively.

\section{CONCLUSION}

The existing study examined the relationship between SPM, BM, and PS with the moderating effect of PG. The results of the study show that SPM has a significant effect on PS. While The BM has a significant effect on PS. The indirect combine effect of SPM and BM on PS is also significantly increase the project success rate. Moreover, the moderating effect of PG is also tested. The result indicates that PG plays the moderating role between SPM, BM, and PS.

\section{REFERENCES}

[1] Joselin, R., \& Müller, R. (2015). Relationships between a project management methodology and Project success in different project governance contexts. International journal of project management, 33(6), 1377-1392.

[2] Yap, J. B. H., Chow, I. N., \& Shavarebi, K. (2019). Criticality of construction industry problems In developing countries: Analyzing Malaysian projects. Journal of Management in Engineering, 35(5), 04019020.

[3] Larsson, J., \& Larsson, L. (2020). Integration, application and importance of collaboration in Sustainable project management. Sustainability, 12(2), 585.

[4] Cooke-Davies, T. (2002). The "real" success factors on projects. International journal of project Management, 20(3), 185-190.

[5] Müller, R., \& Turner, R. (2007). The influence of project managers on project success criteria and project success by type of project. European management journal, 25(4), 298-309.

[6] Martinsuo, M. (2013). Project portfolio management in practice and in context. International Journal of project management, 31(6), 794-803.

[7] Martinsuo, M., \& Hoverfält, P. (2018). Change program management: Toward a capability for Managing value-oriented, integrated multiproject change in its context. International Journal of Project Management, 36(1), 134-146.

[8] Sirisomboonsuk, P., Gu, V. C., Cao, R. Q., \& Burns, J. R. (2018). Relationships between projects Governance and information technology governance and their impact on project performance. International journal of project management, 36(2), 287-300.

[9] Zwikael, O., Chih, Y. Y., \& Meredith, J. R. (2018). Project benefit management: Setting Effective target benefits. International Journal of Project Management, 36(4), 650-658. https://doi.org/10.1016/j.ijproman.2018.01.02.

[10] Joslin, R., \& Müller, R. (2015). Relationships between a project management methodology and Project success in different project governance contexts. International Journal of Project Management, 33(6), 13771392https://doi.org/10.1016/j.ijproman.2015.03.005.

[11] Joslin, R., \& Müller, R. (2016). The relationship between project governance and project Success. International Journal of Project Management, https://doi.org/10.1016/j.ijproman.2016.01.008.

[12] Radujković, M., \& Sjekavica, M. (2017). Project management success factors. Procardia Engineering, 196, 607-615.

[13] Kisacik, B., Pamuk, O. N., Onat, A. M., Erer, S. B., Hatemi, G., Ozguler, Y., ... \& Direskeneli, H. (2016). Characteristics predicting tuberculosis risk under tumor Necrosis factor- $\alpha$ inhibitors: report from a large multicenter cohort with high Background prevalence. The Journal of rheumatology, 43(3), 524-529.

[14] Alias, Z., Zawawi, E. M. A., Yusof, K., \& Aris, N. M. (2014). Determining critical success Factors of project management practice: A conceptual framework. Procardia-Social and Behavioral Sciences, 153, 61-69.

[15] Radujković, M., \& Sjekavica, M. (2017). Project management success factors. Procardia Engineering, 196, 607-615.

[16] Varajão, J. (2016). Success Management as a PM knowledge areawork-in-progress. Procardia Computer Science, 100, 1095-1102.

[17] Mir, F. A., \& Pinnington, A. H. (2014). Exploring the value of project management: linking Project management performance and project success. International Journal of project management, 32(2), 202-217.

[18] Serra, C. E. M., \& Kunc, M. (2015). Benefits realization management and its influence on Project success and on the execution of business strategies. International Journal Of Project Management, 33(1), 53-66.

[19] Treanor, J. J., Talbot, H. K., Ohmit, S. E., Coleman, L. A., Thompson, M. G., Cheng, P. Y \& Berman, L. (2012). Effectiveness of seasonal influenza vaccines in the United States during a season with circulation of all three vaccine strains. Clinical infectious diseases, 55(7), 951-959.

[20] Serra, C. E. M., \& Kunc, M. (2012). Benefits Realization Management and its influence on Project success, project governance, and execution of business strategy-Analysis Of Brazil, the United Kingdom, and the United States of America. University of Warwick, Coventry, UK

[21] Banerjee, S., Humphrey-Jenner, M., \& Nanda, V. (2015). Restraining overconfident CEOs Through improved governance: Evidence from the Sarbanes-Oxley Act. The Review of Financial Studies, 28(10), 28122858.

[22] Cooke-Davies, T. (2002). The "real" success factors on projects. International journal of project Management, 20(3), 185-190.

[23] Balchev, D., Kiprov, Y., Koychev, I., \& Nakov, P. (2016, June). PMIcool at SemEval-2016Task3: Experiments with PMI and goodness polarity lexicons for community question Answering. In Proceedings of the 10th International Workshop on Semantic Evaluation (SemEval2016) (pp. 844-850).

[24] Chih, Y. Y., \& Zwikael, O. (2015). Project benefit management: A conceptual framework of Target benefit formulation. International Journal of Project Management, 33(2), 352-362.

[25] Breese, R., Jenner, S., Serra, C. E. M., \& Thorp, J. (2015). Benefits management: Lost or found In translation. International Journal of Project Management, 33(7), 1438-1451.

[26] Breese, R., Jenner, S., Serra, C. E. M., \& Thorp, J. (2015). Benefits management: Lost or found In translation. International Journal of Project Management, 33(7), 1438-1451.

[27] Müller, R., Zhai, L., \& Wang, A. (2017). Governance and govern mentality in projects: Profiles and relationships with success. International Journal of Project Management, 35(3), 378-392.

[28] Turner, J. R., \& Keegan, A. (2001). Mechanisms of governance in the project based Organization: Roles of the broker and steward. European management journal, 19(3), 254-267.

[29] Lechler, T. G., \& Dvir, D. (2010). An alternative taxonomy of project management Structures: linking project management structures and project success. IEEE Transactions on engineering management, 57(2), 198-210.

[30] Lechler, T. G., \& Dvir, D. (2010). An alternative taxonomy of project management structures: Linking project management structures and project success. IEEE Transactions on engineering management, 57(2), 198-210.

[31] Biesenthal, C., \& Wilden, R. (2014). Multi-level project governance: Trends and Opportunities. International Journal of Project Management, 32(8), 1291-1308. 
[32] Ul Musawir, A., Serra, C. E. M., Zwikael, O., \& Ali, I. (2017). Project governance, benefit Management, and project success: Towards a framework for supporting organizational strategy implementation. International Journal of Project Management, 35(8),

[33] Mitnick, B. M. (2019). Origin of the theory of agency: an account by one of the theory's originators. Available at SSRN 1020378.1658-1672.

[33] Lundin, R. A., Tryggestad, K., Müller, R., \& Martinsuo, M. (2015). The impact of relational Norms on information technology project success and its moderation through Project governance. International Journal ofManaging Projects in Business.

[34] Bekker, M. C., \& Steyn, H. (2008, July). The impact of project governance principles on project Performance. In PICMET'08-2008 Portland International Conference on Management of Engineering \& Technology (pp. 1324-1330). IEEE.

[35] Elkington, J. (1998). Partnerships from cannibals with forks: The triple bottom line of 21 st-Century business. Environmental quality management, 8(1), 37-51.

[37] United Nations. (2014). Prototype global sustainable development report.

[38] Kivilä, J., Martinsuo, M., \& Vuorinen, L. (2017). Sustainable project management Through project control in infrastructureprojects. International Journal ofProject Management, 35(6), 1167-1183.

[39] Amiril, A., Nawawi, A. H., Takim, R., \& Latif, S. N. F. A. (2014). Transportation infrastructure Project sustainability factors and performance. Procedia-Social and Behavioral Sciences, 153, 90-98.

[40] Fernández-Sánchez, G., \& Rodríguez-López, F. (2010). A methodology to identify sustainability Indicators in construction project management-Application to infrastructure Projects in Spain. Ecological Indicators, 10(6), 1193-1201.

[41] Kivilä, J., Martinsuo, M., \& Vuorinen, L. (2017). Sustainable project management through Project control in infrastructure projects. International Journal of Project Management, 35(6), 11671183.

[42] Silvius, A. G., \& Schipper, R. (2016). Exploring the relationship between sustainability and Project success-conceptual model and expected relationships.SciKA-Association for Promotion and Dissemination of Scientific Knowledge, 4(3), 5-22.

[43] PMI, A. (2013). Guide to the project management body of knowledge (PMBOK guide). In Project Management Institute (Vol. 5).

[44] Martens, M. L., \& Carvalho, M. M. (2016). The challenge of introducing sustainability into

[45] Project management function: multiple-case studies. Journal of Cleaner Production, 117, 29-40.

[46] Carlsson, G. E., Möller, A., Blomstrand, C., Ueda, T., Mizushige, K., Yukiiri, K., \& Yang, C.C. (2003). European stroke initiative recommendations for stroke management-

Update 2003. Cerebrovascular Diseases, 16(4), 311-337.

[47] Gido, J., Clements, J., \& Clements, J. (2014). Successful project management. Nelson Education Technical University, Department of Business

[48] Breese, R. (2012). Benefits realization management: Panacea or false Dawn? International Journal of Project Management, 30(3), 341-351.

[49] Chih, Y. Y., \& Zwikael, O. (2015). Project benefit management: A conceptual framework of Target benefit formulation. International Journal of Project Management, 33(2), 352-362.

[50] Cserháti, G., \& Szabó, L. (2014). The relationship between success criteria and success factors in Organizational event projects. International journal of project management, 32(4), 613-624.

[51] Kylindri, S., Blanas, G., Henriksen, L., \& Stoyan, T. (2012, May). Measuring project outcomes: A review of success effectiveness variables. In Proceedings of 7th Annual MIBIS International Conference (pp. 212-223).

[52] Almajed, A. (2017). Information Technology Project Success in Saudi Arabian Public Organizations: Chief Information Officers' Perceptions (Doctoral dissertation, University Of East Anglia).

[53] Atkinson, R. (1999). Project management: cost, time and quality, two best guesses and a Phenomenon, it's time to accept other success criteria. International journal of project management, 17(6), 337-342.

[54] Biesenthal, C., \& Wilden, R. (2014). Multi- level project governance: Trends and Opportunities. International Journal of Project Management, 32(8), 1291-1308.

[55] Bowen, P. L., Cheung, M. Y. D., \& Rohde, F. H. (2007). Enhancing IT governance practices: A Model and case study of an organization's efforts. International Journal of Accounting information Systems, 8(3), 191-221.

[56] Too, E. G., \& Weaver, P. (2014). The management of project management: A conceptual Framework for project governance. International Journal of Project Management,32(8), 1382-1394.

[57] Meskendahl, S., Jonas, D., Kock, A., \& Gemünden, H. G. (2013). A Boa Gestão de Portfolios deProjetos Compensa-Um Estudo Empírico (No. 76150). Darmstadt.

[58] ITGI, I. (2003). Board Briefing on IT Governance, (ed.). United States of America.

[59] Silvius, G. (2017). Sustainability as a new school of thought in project management. Journal of Cleaner Production, 166, 1479-1493.

[60] Carvalho, M. M., \& Rabechini Jr, R. (2017). Can project sustainability management impact Project success? An empirical study applying a contingent.

[61] Martens, M. L., Kniess, C. T., Martens, C. D.P., \& Carvalho, M. M. (2016). A study of Sustainable innovation in a product development project/Um estudo de inovacao sustentavelem projeto de desenvolvimento de produtos. Revista Exacta, 14(3), 477-495.

[62] Silvius, A. G., \& Schipper, R. (2015). A conceptual model for exploring the relationship between Sustainability and project success. Procardia Computer Science, 64, 334-3. 